\title{
FORMATION OF GULLY EROSION IN THE MYJAVA REGION
}

\author{
Radovan NOSKO ${ }^{1 *}$, Marcela MALIARIKOVÁ ${ }^{1}$, Adam BRZIAK${ }^{1}$, Martin KUBÁŇ ${ }^{1}$
}

\begin{abstract}
The article deals with the problems of the occurrence and formation of gully erosion in the Myjava catchment. Gully erosion is a significant problem in that region of Slovakia. Together with this type of soil erosion, muddy floods, waste ground, economic losses in agriculture, and many other problems are involved. The main objectives of this article are an analysis of the occurrence of gully erosion in the Myjava region in different periods of time and identification of the most significant factors that have impacted the formation of the gully network. The appearance of gully erosion has been identified from historical maps and other historical documents preserved from the region. The factors analysed were mainly human activities that resulted in changes in land use and physical-geographic catchment characteristics such as the soil, the geology, and the morphology. Nowadays, we are seriously lagging behind in dealing with this issue compared to other European countries.
\end{abstract}

\section{Address}

1 Dept. of Land and Water Resources Management, Faculty of Civil Engineering, Slovak University of Technology, Bratislava, Slovakia.

* Corresponding author: radovan.nosko@stuba.sk

\section{Key words}

- Myjava catchment,

- Gully erosion,

- Land use change,

- Historical maps.

\section{INTRODUCTION}

Nowadays, the term "soil degradation" is frequently discussed in the field of environmental protection. Soil erosion is one of the most crucial problems that cause soil degradation and losses. In certain regions of the Slovak Republic, water and wind erosion can especially be identified (Hlavčová, 2011). Water erosion is a continual process; it results in thinning the soil profile, loosening fine soil particles and nutrients, and degrading the soil structure and texture. It can also cause significant changes in a water regime. According to Borka (1988), the term "soil erosion" is understood to relate to changes in a landscape's structure (denudation, transport, and accumulation), especially by human activities combined with water or wind. Water erosion can be divided into several forms, and gully erosion is one of the most intensive. The formation of gullies is quite a slow process. It starts when the kinetic energy of rain causes the sheet form of erosion, thereby resulting in thinning of the soil layer and the appearance of small channels. The destruction of the top of the soil layer appears after a longer period. During heavy rains, these smaller channels are gradually connected to more significant depressions called rills. The last stage is the formation of a gully through the connection of several rills. As a result of these erosion features, a large number of soil particles, nutrients and also hazardous chemicals (pesticides and different types of fertilizers), are transported and accumulate on lower parts of slopes (Ilavská, Jambor, Lazúr, 2005).

According to time-area criteria, erosion gullies are divided into permanent and ephemeral. While ephemeral gullies can be removed by tillage, permanent gullies need to be stabilized. In this contribution, we will focus on the formation and identification of permanent gullies, which create a continuous network in some areas (Holý, 1978). The densest networks of gullies can be located on hilly lands and lower highlands. Gullies are also found in areas with lower resistance to stream processes (Hofierka, 2005). Authors such as Stankoviansky (2004), Hofierka (2005), Papčo (2011), and Midriak (2011) have published scientific papers on the formation of gully erosion on the territory of Slovakia. This paper focuses on an analysis of the gully erosion that occurs in the Myjava river basin, which has been described in Stankoviansky $(1997,2004,2008,2010)$. Many slopes 


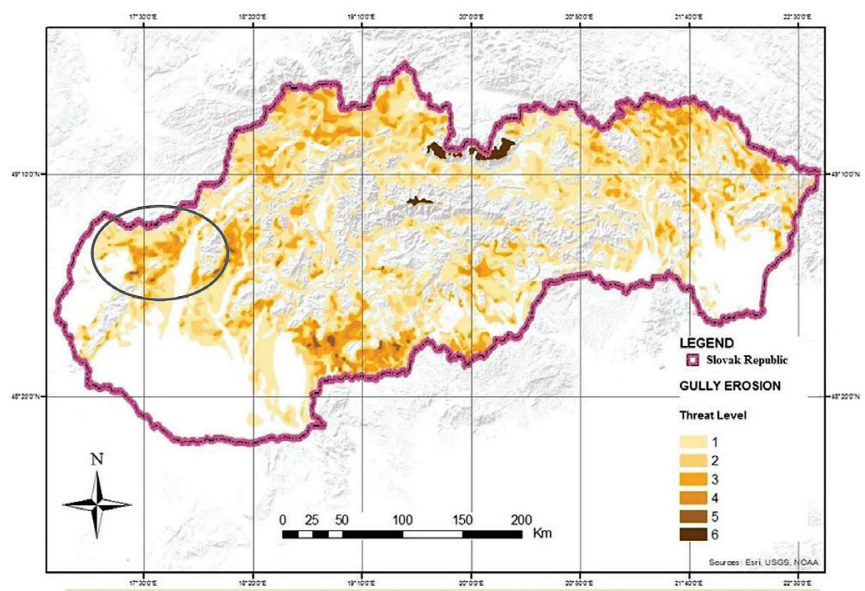

Fig. 1 Occurrence of the network of permanent gullies (the Myjava river basin is highlighted) by Bučko, Mazúrová (1958) in Stankoviansky, Pišút (2011)

with a high degree of steepness and dry valleys are located in this basin. A large number of gullies are located in a relatively small area. It is evident that this region has significantly been stricken by gully erosion, as shown in Fig. 1. This gully erosion map was produced in the 1960s by Bučko and Mazurová (1958). They divided the territory of Slovakia onto a square network and measured the density of gullies in the individual squares.

\section{DESCRIPTION OF THE MYJAVA CATCHMENT}

The Myjava catchment is located in western Slovakia; part of the catchment borders on the Czech Republic. The Myjava River and its tributaries form a river network with a length of $79 \mathrm{~km}$; the size of the whole catchment is $625 \mathrm{~km}^{2}$. The landscape is strongly affected by human activity; the most significant changes in the land use can mainly be seen in the Myjava highlands. These changes result from the period of "kopaničiarska" colonization $\left(16^{\text {th }}-18^{\text {th }}\right.$ centuries $)$ with its extensive deforestation and the period of agricultural collectivization (1940 - 1990). Most of the catchment has undergone typical rapid runoff processes, which produce mud floods and cause rills and gully erosion. The southern part of the watershed is located in the Brodská lowlands, where the effects of water erosion are minimal.

The area under study belongs to a less rugged geomorphological entity. The northern part of the river basin is mostly formed by the White Carpathian Mountains; the Myjavská and Chvojnická high- lands are in the middle part, while the Borská lowland is in the southern part (Fig. 2). The geological structure of the river basin is $30 \%$ grey siltstone and claystone. Its higher parts are mostly represented by cambisol with pararendzinas, dolomites, and marls; conglomerates mostly appear in the eastern part. The lowlands are formed by calcium clays, silts deposited by the Morava River (fluvisol, regosol), and gravel. The most frequently occurring kinds of soil are clay soil, which is mostly located in the northern part of the river basin, and sandy soil in the southern regions.

Most of the area lies in a warm or mild region with an annual average air temperature of $10^{\circ} \mathrm{C}$ and where a northerly - northwesterly wind flow with a maximum average speed of $60 \mathrm{~km} \cdot \mathrm{h}^{-1}$ dominates. The average annual precipitation in the river basin is $550-600 \mathrm{~mm}$ and around $900-1000 \mathrm{~mm}$ in the northern parts. The natural vegetation is mainly forest communities, which are mostly represented by deciduous forests, while mixed and coniferous forests are located in higher parts of the river basin (Maliariková et al., 2016).

\section{SETTLEMENT OF THE AREA AND GULLY FORMATION}

Human effects in the region are closely connected with the cultivation of soil, producing grain, the domestication and breeding of animals, the manufacture of wooden tools and pottery, and constructing dwellings. This conscious use of the land is called the "Neolithic revolution" (roughly 12,000 years ago). Areas for constructing dwellings were cleared. These interventions in the region led to the creation of various linear pathways of runoff, which eventually led to erosion that caused gullies or ravines (Kvitkovič, 2005).

Nowadays, the Myjava catchment belongs among the areas most endangered by gully erosion. By the 18th century, people already realized that problems with deforestation were connected with gully erosion. The primary settling of the Myjava catchment was connected with the construction of the Branč castle and adjacent villages, which changed the natural character of the region to cultivated land. The second settlement phase was connected with the "kopaničiarska" colonization, which, as mentioned above, developed from the 16th to the 18th centuries (Tab.1). Colonization also started in the higher and more remote parts of the catchment; it was connected with the cultivation of fields, meadows, and pastures and also with intensive deforestation of the natural forest communities (Žarnovičan, 2008). The region has characteristic narrow, mosaic fields, which are regularly rotated and are used as agricultural land, meadows, pastures, and forest communities (Heinrichová, 2012). The Myjava highlands is a region where the intensive "kopaničiarska" settlement caused extreme gully erosion.
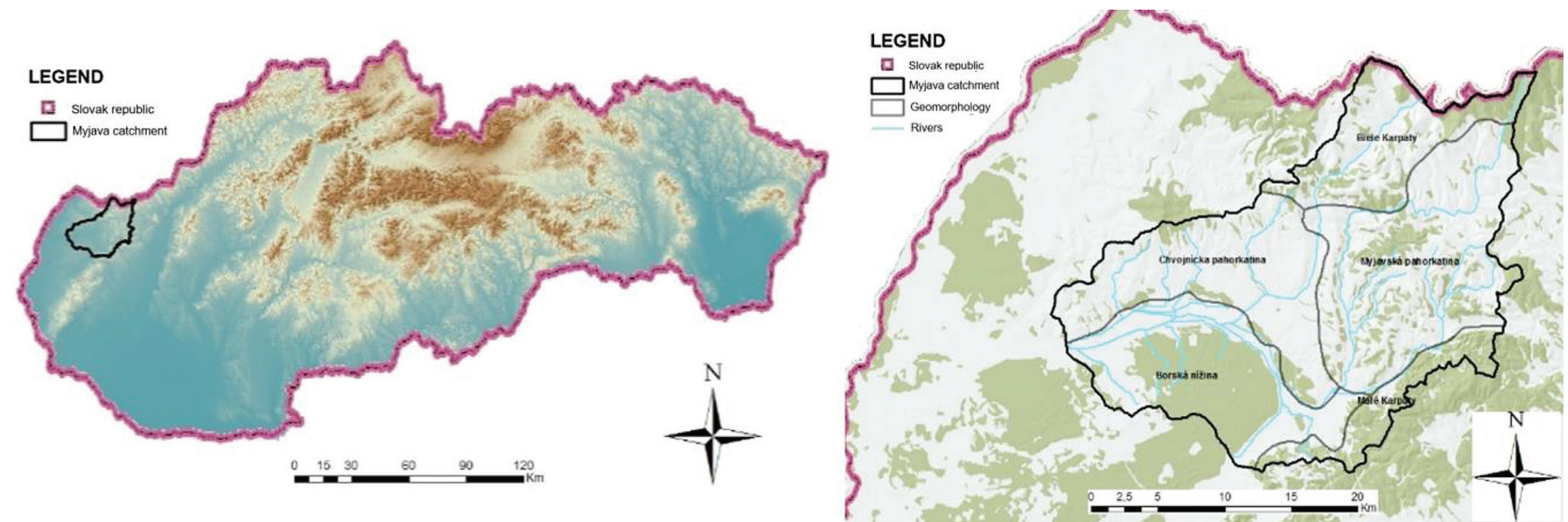

Fig. 2 Location of the Myjava catchment in Slovakia 
Tab. 1 Settlement in the Myjava catchment (Atlas of the Landscape of the $S R(A K S R))$

\begin{tabular}{|c|c|c|c|c|}
\hline Century & Castles & Towns & Villages & Total \\
\hline 10th & 1 & 1 & 0 & 2 \\
16th & 1 & 1 & 22 & 24 \\
19th & 1 & 5 & 23 & 29 \\
\hline
\end{tabular}

Some theories assert that the area had already been stricken by erosion in the 14th century during the Little Ice Age, which was before intensive settlement of those lands (Stankoviansky, 2004). Stankoviansky opined that the current relief appearance of most of the Myjavská highlands is the result of the combined effects of agricultural activity (mostly plowing) and acceleration of the surface runoff. In the region of Brezová pod Bradlom (the Myjava highlands in the Brezová Carpathians), the effect of extreme precipitation (floods in $1736,1737,1783,1784,1792,1813,1815$, and 1820) caused the formation of gullies together with melting snow [1].

Another negative phenomenon related to the settlement and deforestation of the area was the occurrence of abandoned lands (badlands). The collectivization of agriculture in the 20th century had a significant impact on the already devastated soil. Land consolidation led to the destruction of terraces, which belonged among the most valuable landscape elements. The creation of very large agricultural fields influenced the occurrence of mud floods and the formation of gullies during intense rainfalls (Stankoviansky, 1997).

Badlands are soils where as a result of human activity, the permanent vegetation cover (mostly forests) was removed, and as a result of subsequent processes (wind and water erosion and the mining of mineral resources), the soil profile has been depleted or removed (Midriak, 2011). The "badlands" theme has been discussed by other authors in the last decade (see Du Pisani (2003), Midriak (2003), Boerma (2006), Goudie, Boardman (2010), etc.) The Myjava highlands and the White Carpathians belong among the regions most afflicted by badlands in Slovakia (Fig. 3). Nowadays, on the basis of research, there is an assumption of gully erosion, especially on badlands, that was created by heavy industrialization. They are mainly abandoned heaps on soil where mining in a quarry was finished, as well as the forest soil fund and soil that was devastated by the transport of heavy military machinery. These places that have steeper terrain slopes face a real danger of landslides and rill or sheet erosion and gullies (Midriak, 2011).

The importance of gully erosion can also be proved by some settlements whose names include words meaning small streams or gullies. The creation of a gully is often connected with anthropogenic activities, e.g., the building of linear features such as roads for fields or the borders of agricultural parcels. Some gullies are marked on historical maps as temporary streams. From a historical point of view, the mouths of valleys represented an entrance door to the mountains, which then led to the construction of forest roads that eventually transformed into ephemeral or permanent gullies (Pišút, 2016). Mud floods are also an accompanying phenomenon of gully erosion. The most significant mud floods in the Myjava catchment were detected in the year 2009; the villages of Kunov and Prietrž were the most affected (Fig. 4) (Stankoviansky, 2010).

\section{MATERIAL AND METHOD}

As a significant landscape factor, gullies have their place in cartographic documents. Maps mainly document gully erosion from the period of the 1st military mapping (1763-1785, when Slovakia was in the Austro-Hungarian Empire), subsequent military maps as well as newer cartographic maps (Papčo, 2005). The role of the military mapping was to simplify the orientation in a terrain during military operations, so gullies were an obstacle that did not have to be drawn on the map. For that reason, some gullies were omitted because they were not relevant for military purposes (Klein, 2002).

In this study, the appearance of gullies was analyzed in different periods (Fig. 5); we subsequently created a map of the gully erosion for each time horizon. The identification and vectorization of gullies were created on the map from the first military mapping (1763-1785, i.e., 1. MM), the 3rd military mapping (1869-1887, i.e., 3. MM), a topographic map on a scale of 1:25,000 (1953-1957, i.e., TM 25), and a basic map of the SR on a scale of 1:50,000 (2000, i.e., BM 50). The vectorization of the gullies was made using the ArcGIS program.

In the process of the vectorization of the gullies, we focused on the occurrence of the gullies and their lengths and areas, which were drawn on the maps. On the map from the 1st military mapping, the identification of gullies was more laborious because of the low graphic quality of the map (Fig. 5a). For this period we identified and vectorized 215 gullies with a total length of $118 \mathrm{~km}$ and a density of $0.19 \mathrm{~km} / \mathrm{km}^{2}$. However, in terms of the quality of the maps and the purposes of military mapping, some gullies were not marked. Most of the gullies were located in the Myjava highlands (around 146).

On the maps from the 3rd military mapping (1869-1883), the identification of the gullies was more explicit. The process of identification was more complicated because these maps are available only as black and white copies. We identified and vectorized 511 gullies with a total length of $209 \mathrm{~km}$ and a density of $0.33 \mathrm{~km} / \mathrm{km}^{2}$. Again, most of the gullies were located in the Myjava highlands (around 269).
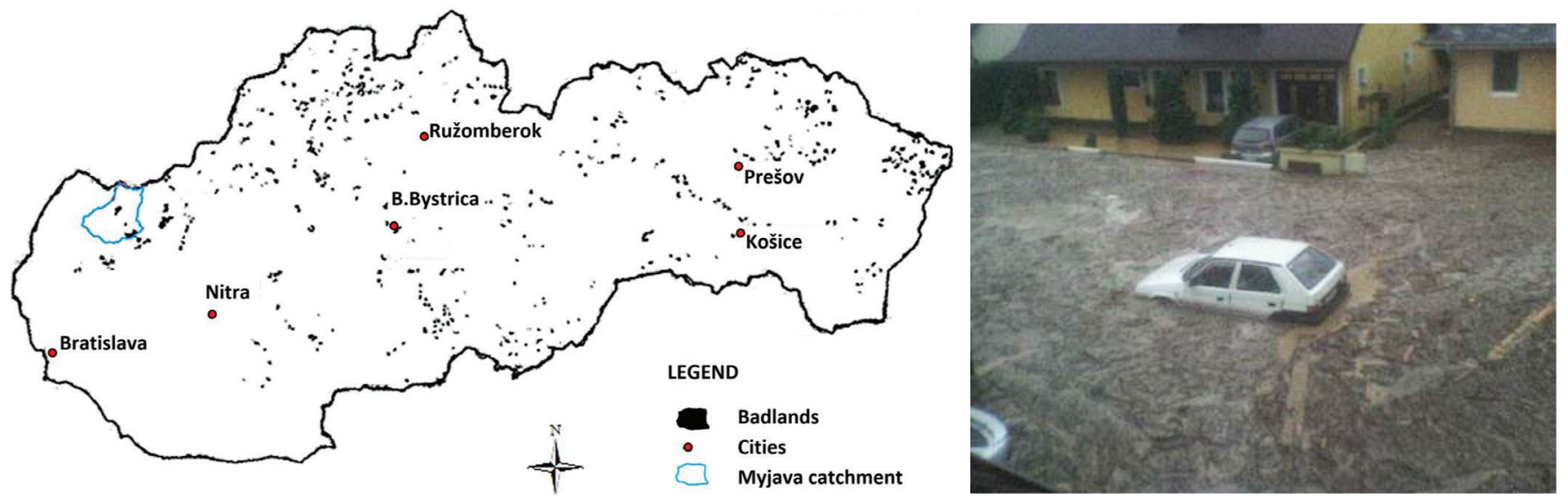

Fig. 3 Appearance of badlands in the SR by Janečko (1955), Midriak (2011).

Fig. 4 Mud flood in Kunov 2009 (Stankoviansky, 2010) 

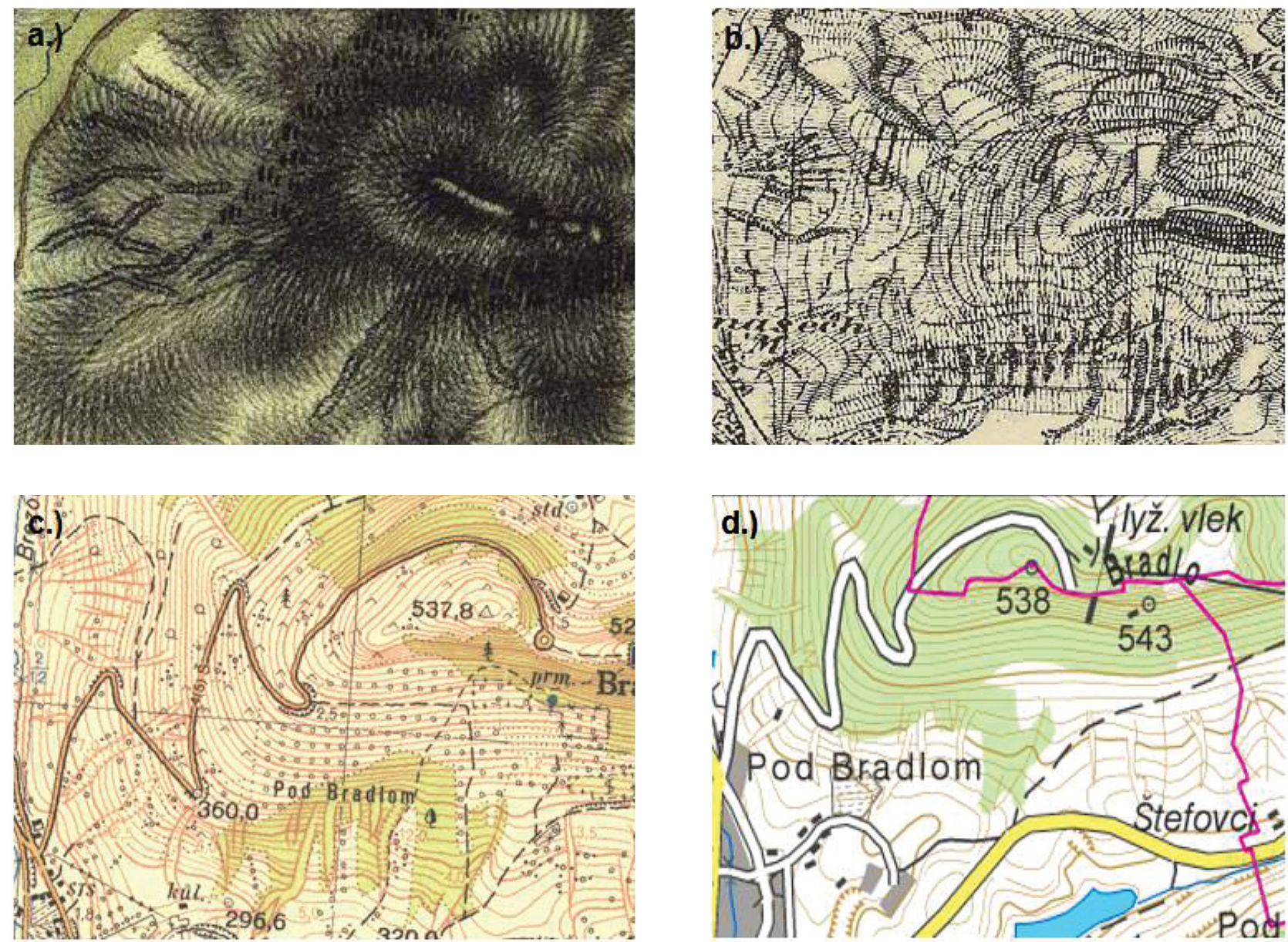

Fig. 5 Identification of gully erosion in parts of the Myjava catchment on the selected maps (a.) 1. MM, b.) 3. MM, c.) TM 25, d.) BM 50).

On the topographical map from the middle of the 20th century (1953-1957) on a scale of 1:25,000, we identified the most significant number of gullies, i.e., 754. It is interesting to note that despite a 50 $\%$ growth in gullies in comparison with the 3 rd military mapping, we observed a decrease in the total length of the gullies and only a minimal increase in their areas. This fact can be explained by how gullies are drawn on topographical maps. In many cases the gullies were only marked as a line (loss of area). On the other hand, most of the gullies are presently in forests, which resulted in a more laborious mapping of the total lengths (loss in lengths).

On the basic map of the SR on a scale of 1:50,000, we identified and vectorized 475 gullies, which were approximately 300 gullies fewer than in the middle of the 20th century. Many gullies located on the BM 50 were located in densely forested areas, where it was not possible to identify them. A significant decrease in gullies was detected in the areas of the White and Small Carpathians. The density of the occurrence of gullies in this period is around $0.34 \mathrm{~km} / \mathrm{km}^{2}$. However, the scale of the map and the purposes for its use had the greatest effect on the decrease in gullies identified.

\section{RESULTS OF THE VECTORIZATION AND IDENTIFICATION OF THE GULLY EROSION}

The identification of the gullies that are the subject of this paper is documented in Tab.2. The localization of the gullies in the individual geomorphological units in the catchment is shown in Tab.3.

The density of the erosion gullies in some districts even reaches higher values (Stankoviansky, 2010). He points out a network of permanent gullies of the badland region near the village of Vad'ovce with a density of $11 \mathrm{~km} / \mathrm{km}^{2}$ (Fig. 6a). Another example of badlands in the Myjava catchment is Periska in the Brezovské Carpathians (Fig. 6b) (Midriak, 1966).

Tab. 2 Identification of the gullies on the historic maps

\begin{tabular}{ccccc}
\hline Map & Number of gullies & Area $\left(\mathbf{k m}^{2}\right)$ & Length $(\mathbf{k m})$ & Density $\left(\mathbf{k m} / \mathbf{k m}^{2}\right)$ \\
\hline 1. MM & 215 & 4.40 & 118 & 0.19 \\
3. MM & 511 & 8.34 & 229 & 0.33 \\
TM 25 & 754 & 6.76 & 261 & 0.42 \\
BM 50 & 475 & 10.50 & 214 & 0.34 \\
\hline
\end{tabular}



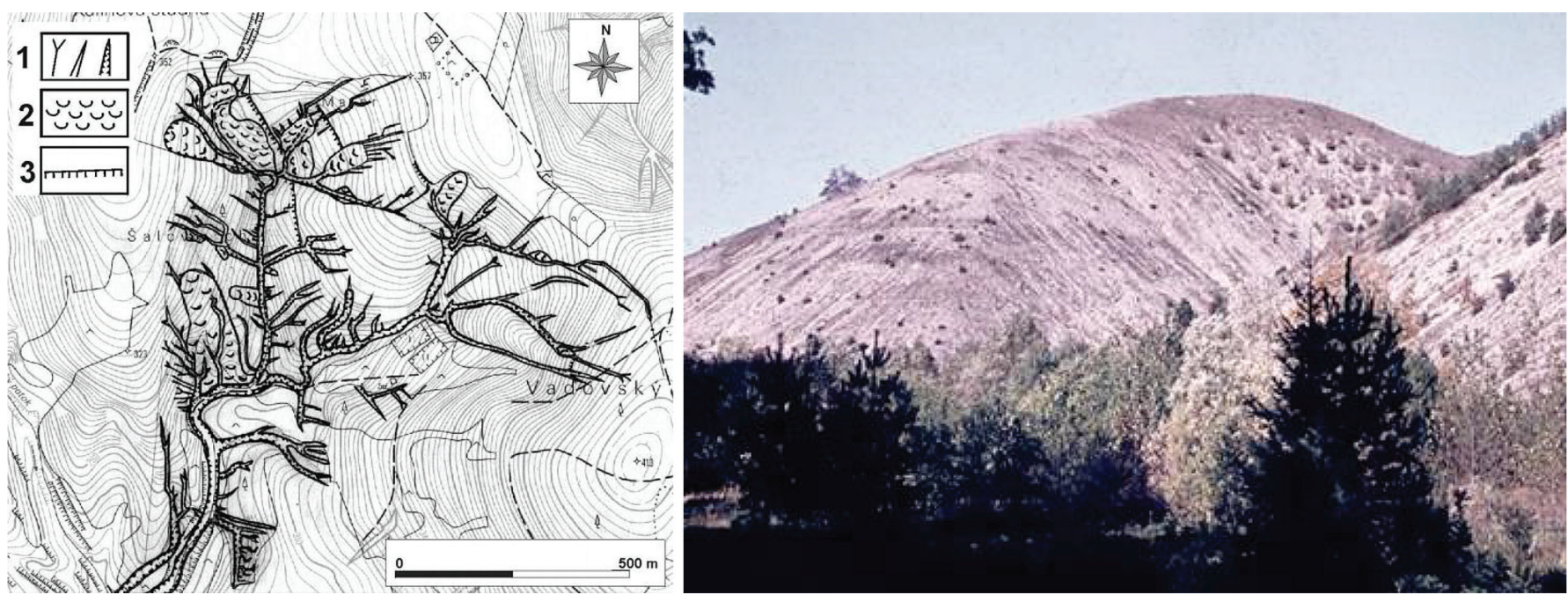

Fig. 6a) The network of permanent gullies of the badlands near the village of Vad'ovce (Stankoviansky, 2003), 6b) Badlands in the Brezovské Carpathians - Periská (Midriak, 1966)

Tab. 3 Localization of gullies in the geomorphological units

\begin{tabular}{|c|c|c|c|}
\hline Map & Geomorphological unit & Number of gullies & Density $\left(\mathrm{km} / \mathrm{km}^{2}\right)$ \\
\hline \multirow{5}{*}{ 1. MM } & Myjavská highlands & 146 & 0.41 \\
\hline & Chvojnická highlands & 30 & 0.10 \\
\hline & White Carpathians & 2 & 0.01 \\
\hline & Small Carpathians & 22 & 0.36 \\
\hline & Borská lowlands & 15 & 0.10 \\
\hline \multirow{5}{*}{ 3. MM } & Myjavská highlands & 310 & 0.53 \\
\hline & Chvojnická highlands & 95 & 0.37 \\
\hline & White Carpathians & 37 & 0.19 \\
\hline & Small Carpathians & 56 & 0.88 \\
\hline & Borská lowlands & 13 & 0.08 \\
\hline \multirow{5}{*}{ TM 25} & Myjavská highlands & 452 & 0.69 \\
\hline & Chvojnická highlands & 94 & 0.29 \\
\hline & White Carpathians & 129 & 0.47 \\
\hline & Small Carpathians & 87 & 0.77 \\
\hline & Borská lowlands & 42 & 0.07 \\
\hline \multirow{5}{*}{ BM 50} & Myjavská highlands & 263 & 0.53 \\
\hline & Chvojnická highlands & 78 & 0.32 \\
\hline & White Carpathians & 56 & 0.23 \\
\hline & Small Carpathians & 44 & 0.51 \\
\hline & Borská lowlands & 34 & 0.09 \\
\hline
\end{tabular}

In comparison with the 1st military mapping, we observed the most significant growth of gullies in the White Carpathians. In all the mapping periods, the region most damaged by gullies is the Myjavska highlands. Based on the identification of the gullies (Tab. 2) and their localization within the geomorphological units (Tab. 3), a map of the gully erosion for all the mapping periods was created. The areas of the gullies estimated from the maps is documented in (Tab. 4). The results of this analysis represent a historical network of the gullies.

It is evident from Fig. 8 that the gully erosion in the Myjava catchment is mostly situated in the Myjava highlands, part of the Small Carpathians, and the western part of the Chvojnická highlands.
Tab. 4 The sizes of the areas damaged by gully erosion

\begin{tabular}{ccc}
\hline Map & Area $\left(\mathbf{k m}^{2}\right)$ & Area percentage (\%) \\
\hline 1. MM & 75.56 & 12.1 \\
3. MM & 136.31 & 21.8 \\
TM 25 & 204.2 & 32.7 \\
BM 50 & 168.8 & 27.0 \\
AKSR & 153.9 & 24.6 \\
\hline
\end{tabular}



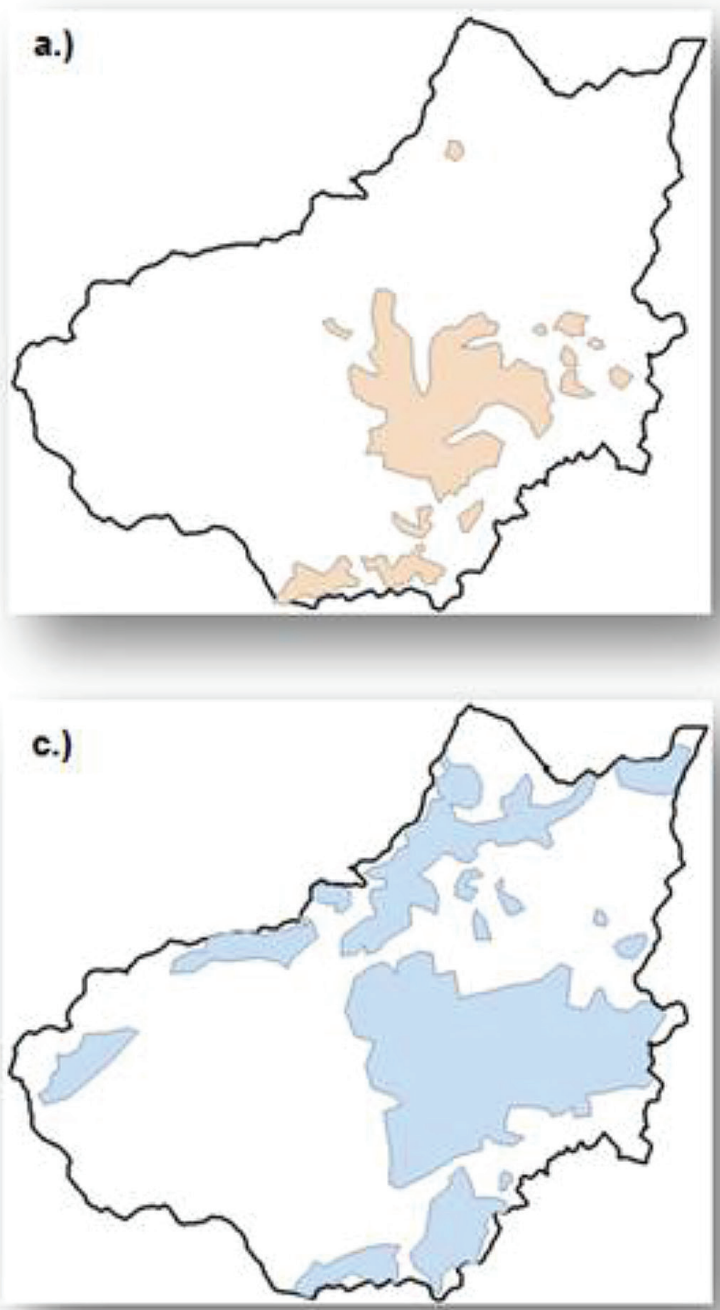

Fig. 7 Maps of the areas damaged by gullies in the catchment (a.) 1. MM, b.) 3. MM, c.) TM 25, d.) BM 50)
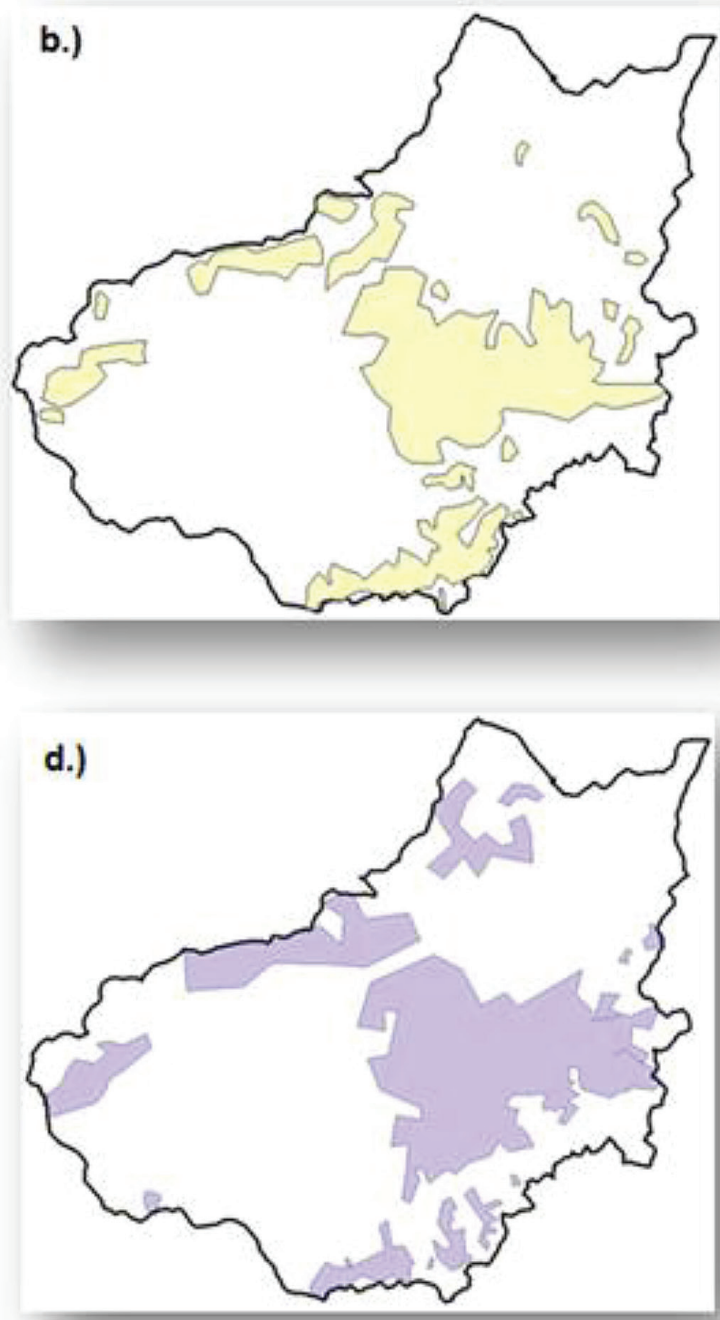

On the TM 25 map, we can also see that they increased in the northern parts of the territory. It is also evident that in the middle of the $20^{\text {th }}$ century, $30 \%$ of the Myjava catchment was endangered by gully erosion. In the case of the BM 50, we can see a decrease in the areas subject to gully erosion. This decrease was caused by difficulties with

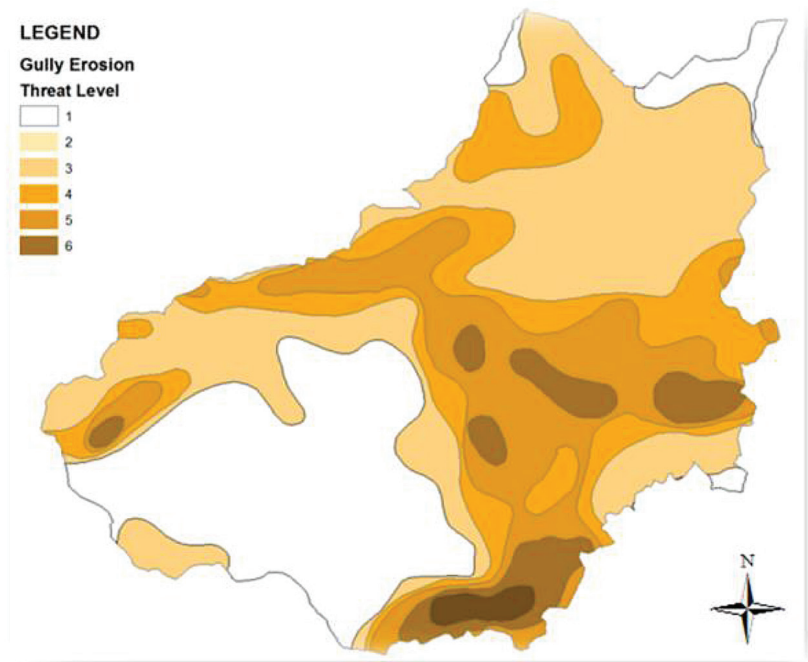

Fig. 8 Gully erosion shown by the Atlas of the Landscape of the SR (AKSR) the identification of gullies located in forested areas (mostly in the territory of the White Carpathians). In the present, a third of the catchment is still endangered by gully erosion. Fig. 8 shows the extent of gully erosion based on the Atlas of the Landscape of the SR (Bučko, Mazurová, 1958).

\section{IMPACT OF DIFFERENT FACTORS ON THE CREATION AND DEVELOPMENT OF GULLY EROSION IN THE MYJAVA CATCHMENT}

In the next part of the research, we analysed the occurrence of the gullies as related to land use, geology, soil types, and climate. The land use maps were processed by the identification and vectorization of the land use or land cover categories on the selected maps (1. MM, TM 25). Other factors were identified according to the maps in the Atlas of the Landscape of the SR, with the focus on the soil and geological catchment characteristics. The soil characteristics were represented by the soil types and textures. The geology was characterized by a division of the catchment into geological regions. The catchment consists of 9 geological regions that were attacked by gully erosion. Only the northern part of the area is almost homogeneous and includes flysch rocks. The occurrence of the gullies was processed using the ArcGIS program. 
Tab. 5 Percentual representation of selected land use categories

\begin{tabular}{llll}
\hline Land use category & 1. MM (\%) & TM 25 (\%) & CLC (\%) \\
\hline Arable land & 61.7 & 54 & 44.7 \\
Low grasses & 13.8 & 8.9 & 12.7 \\
Coniferous forest & 9.6 & 11.5 & 9.3 \\
Deciduous forest & 12.2 & 10.3 & 22.4 \\
Mixed forest & - & 4.5 & 2.5 \\
Forest - scrub & - & 5.4 & 3.6 \\
Urbanized area & 2.7 & 5.4 & 4.5 \\
Water area & - & - & 0.3 \\
\hline
\end{tabular}

The description of the changes in land use in the Myjava catchment is described in Valent et al. (2016). The percentual representation of the selected land use categories for the maps of 1. MM, TM 25, and the current land use from the Corine Land Cover vector data (2010, i.e., CLC) is shown in Tab.5. The CLC provides current satellite land use data for 38 European countries.

In the period of the 1 st military mapping (1.MM), almost $88 \%$ of the gullies were located on arable lands, and only $12 \%$ occurred in forested areas or grasslands. In the middle of the 20th century (TM 25 ), this ratio had significantly changed. Almost $72 \%$ of the gullies detected were covered with vegetation (coniferous forest, deciduous forest, forest-scrub, and low grasses); $27 \%$ occurred on arable lands; and only $1 \%$ of the gullies occurred in urban areas. The 3rd military map (3. MM) is only preserved in black and white, and vectorization
Tab. 6 The number of gullies covered by vegetation

\begin{tabular}{clll}
\hline Period $\begin{array}{l}\text { Land use } \\
\text { category }\end{array}$ & $\begin{array}{l}\text { Number } \\
\text { of gullies }\end{array}$ & $\begin{array}{l}\text { \% of } \\
\text { occurrence }\end{array}$ & $\begin{array}{l}\text { \% on arable } \\
\text { land and other } \\
\text { categories }\end{array}$ \\
\hline Arable land & 189 & 88 & $88 \%$ \\
Deciduous forest & 10 & 5 & \\
1. VM Coniferous forest & 0 & 0 & $12 \%$ \\
Low grasses & 16 & 7 & \\
Urbanized areas & 0 & 0 & $27 \%$ \\
\hline Arable land & 203 & 27 & \\
Deciduous forest & 186 & 25 & \\
Coniferous forest & 171 & 23 & $73 \%$ \\
TM 25 Mixed forest & 76 & 10 & \\
Low grasses & 64 & 8 & \\
Forest-scrub & 47 & 6 & \\
Urbanized areas & 7 & 1 & \\
\hline
\end{tabular}

of the land use on that map was not possible. The described results are shown in (Tab.6).

Based on the soil texture, almost the whole catchment belongs among regions where loamy soils are representative. The most representative soil types are cambisol and brown soil. The occurrence of gullies according to the soil characteristics is shown in Tab.7.

Tab. 7 Occurrence of gullies based on soil types

\begin{tabular}{|c|c|c|c|c|c|}
\hline Period & Soil type & Number of gullies & Period & Soil type & Number of gullies \\
\hline \multirow{10}{*}{ 1. MM } & Black earth & 0 & \multirow{10}{*}{ TM 25} & Black earth & 0 \\
\hline & Meadow black earth & 3 & & Meadow black earth & 2 \\
\hline & Fluvial soil & 4 & & Fluvial soil & 6 \\
\hline & Brown soil & 61 & & Brown soil & 154 \\
\hline & cambisol & 79 & & cambisol & 362 \\
\hline & Luvisol soil & 31 & & Luvisol soil & 98 \\
\hline & Organogenous soil & 0 & & Organogenous soil & 0 \\
\hline & Pararendzinas soil & 11 & & Pararendzinas soil & 43 \\
\hline & Regosol soil & 0 & & Regosol soil & 2 \\
\hline & Rendosol soil & 26 & & Rendosol soil & 87 \\
\hline \multirow{10}{*}{ 3. MM } & Black earth & 0 & \multirow{10}{*}{ BM 50} & Black earth & 0 \\
\hline & Meadow black earth & 5 & & Meadow black earth & 4 \\
\hline & Fluvial soil & 5 & & Fluvial soil & 9 \\
\hline & Brown soil & 139 & & Brown soil & 122 \\
\hline & cambisol & 188 & & cambisol & 172 \\
\hline & Luvisol soil & 93 & & Luvisol soil & 68 \\
\hline & Organogenous soil & 0 & & Organogenous soil & 0 \\
\hline & Pararendzinas soil & 25 & & Pararendzinas soil & 34 \\
\hline & Regosol soil & 2 & & Regosol soil & 6 \\
\hline & Rendosol soil & 54 & & Rendosol soil & 60 \\
\hline
\end{tabular}


Tab. 8 Comparing the badlands and occurrence of gullies, in terms of soil types.

\begin{tabular}{llll}
\hline Badlands in Slovakia (Midriak, 2011) & \% of occurrence & Gully erosion in Myjava catchment & \% of occurrence \\
\hline Cambisol soil & 53.0 & Cambisol soil & 36 \\
Rendzinas soil & 22.0 & Rendzinas soil & 13 \\
Brown soil & 5.6 & Brown soil & 26 \\
Fluvisol soil & 5.3 & Fluvisol soil & 2 \\
Luvisol soil & 2.6 & Luvisol soil & 14 \\
Pararendzinas soil & 1.9 & Pararendzinas soil & 7 \\
Others & 7.5 & Others & 2 \\
\hline
\end{tabular}

Tab. 9 Occurrence of gullies on soils divided according to the soil texture

\begin{tabular}{|c|c|c|c|c|c|}
\hline Period & Granularity & Number of gullies & Period & Granularity & Number of gullies \\
\hline \multirow{6}{*}{ 1. $M M$} & Clay-sandy soil & 0 & \multirow{6}{*}{$T M 25$} & Clay-sandy soil & 0 \\
\hline & Clay & 175 & & Clay & 653 \\
\hline & Sandy-clay soil & 29 & & Sandy-clay soil & 69 \\
\hline & Sandy soil & 2 & & Sandy soil & 2 \\
\hline & Clay-loam soil & 9 & & Clay-loam soil & 26 \\
\hline & Loam & 0 & & Loam & 4 \\
\hline \multirow{6}{*}{ 3. $M M$} & Clay-sandy soil & 0 & \multirow{6}{*}{ BM 50} & Clay-sandy soil & 0 \\
\hline & Clay & 437 & & Clay & 386 \\
\hline & Sandy-clay soil & 54 & & Sandy-clay soil & 62 \\
\hline & Sandy soil & 5 & & Sandy soil & 7 \\
\hline & Clay-loam soil & 12 & & Clay-loam soil & 17 \\
\hline & Loam & 3 & & Loam & 3 \\
\hline
\end{tabular}

The most intensive occurrence of the erosion gullies is evident on the cambisol, luvisol, and rendzinas soils. Cambisol soils, which are mostly located on slopes, are, in terms of their ecological stability, often eroded, which leads to the forming of gullies, thereby endangering water resources. There are also fragments of rendzinas in the cambisol soils, which also belong among soils significantly threatened by gully erosion. More than three quarters of the badlands on the Slovak territory are connected to the cambisol and rendzinas soil types. Nowadays, these soils are mainly forested (Midriak, 2011). Brown soils were initially mostly forested, but under the influence of the "kopaničiarska" colonization, the majority of the brown soils are used as arable lands. Brown soils, especially on undulating terrains, are often eroded in periods of rainstorms. Also, luvisol soils originally belonged to the forested soils, but in the past, they were deforested and used for crop cultivation or animal breeding. These soils represent ideal conditions for water erosion (Bedrna, 1968), especially on the Myjava highland relief. Tab. 8 compares the badlands in Slovakia according to Midriak (2011) and the gully erosion in the Myjava catchment. In the table, we document the connection between the badlands, gullies, and soil types.

The mentioned soil types mainly occur on medium heavy and heavy soils, which were mostly forested in the past. Gully erosion is most frequently detected on loamy soils (medium-heavy soils), e.g., Tab. 9 (Bedrna, 1968)

\section{CONCLUSION}

This paper focuses on the influences that have caused gully erosion in the Myjava River catchment. The Myjava catchment contains a lot of valleys and ravines. There is a significant network of gullies and erosion furrows, the occurrence and formation of which we have monitored on historical maps. The first map that shows the catchment in more detail is the First Military Mapping, which was designed to map routes for military operations. For this reason, not all the gullies were marked on the map. Two hundred gullies were identified, the formation of which was influenced by the Little Ice Age and anthropogenic factors.

Human activities have affected the area in terms of changes in the landscape's structure. During the "kopaničiarska" colonization, the deforesting of the area occurred, which made ideal conditions for the formation of gullies. Nearly $90 \%$ of the detected gullies were connected to arable lands. The map from the 3rd Military Mapping shows a $50 \%$ growth in gullies, since it is a more detailed cartographic map. Another map used for the analysis was a topographical map (TM25) on a scale of 1:25, 000 from the middle of the 20th century, where we can again observe a significant increase in gullies, mostly on the territory of the White Carpathians. From the point of view of the land use, the occurrence of gullies has changed, and approximately three quarters of the erosion gullies are now located on land that was covered by vegetation (deciduous forests, coniferous forests, scrub, and grass). The last map used was a basic map of the SR on a scale of 1: 50,000, 
where we identified 475 gullies. Compared with the TM 25, a lot of the gullies were located on high-density forested areas, which makes their identification close to impossible. Based on the completed analysis, we made a map of the gully erosion threats for the monitored period and area, which were compared with a map made by AKSR.

Together with extreme rain phenomena and human activities, the character of the region (e.g., soil types and slopes of terrains) also has a huge effect on the occurrence of gullies. The slope of the terrain is most significant in parts of the Myjavska highlands, which in each period were attacked by the erosion of the gullies. From our identification and subsequent analysis, we concluded that in a slope terrain area with an occurrence of medium heavy and heavy soil, significant gully erosion occurred, which was affected by intensive agricultural work. The soil types most attacked on the cultivated slopes and badlands are the cambisol, luvisol, and rendosol.

From the analysis made in this contribution, it is evident that the formation of gullies is a combination of many factors. There is a sig- nificant correlation between the origin of badlands and destroyed agricultural land. The occurrence of gully erosion is more frequent on badland soils because of accelerated surface runoff. A large amount of the gullies were formed due to human activities and were connected by linear elements (field roads, forest roads, terraces, or slope deforesting and subsequent use as agricultural lands). However, in the period of the settlement of lands, more gullies were already located, which confirms that a significant role in erosion is played by climatic factors together with land characteristics.

\section{Acknowledgments}

This work was supported by the Slovak Research and Development Agency under Contracts No. APVV-15-0497 and the VEGA Grant Agency No. 1/0891/17. The authors thank the agencies for their research support. 


\section{REFERENCES}

Bedrna, Z. - Hraško, J. - Sotáková, S. (1968) Agriculture Soil Science (Pol'nohospodárske pôdoznalectvo), Slovak Publishing House of Agricultural Literature, Bratislava, $362 \mathrm{pp}$.

Boerma, P. (2006) Assessing Forest Cover Change in Eritrea - A historical perspective, Mountain Research and Development, Vol. 26, No. 1, pp. 41-47.

Bork, H. R. (1988) Bodenerosion und Umwelt - Verlauf, Ursachen und Folgen der mittelalterlichen und neuzeitlichen Boden erosion, Landschaftsgenese und Landschaftsökologie, vol. 13, Technische Universität Braunschweig. 249 pp.

Bučko, Š. - Mazúrová, V. (1958) Gully Erosion in Slovakia, Zachar, D., Water erosion in Slovakia (Výmol'ová erózia na Slovensku), In: Zachar, D., Vodná erózia na Slovensku), Bratislava, pp. 68101.

Du Pisani, J. A. (2003) Environmental History, Remote Sensing and Change Detection: an Interdisciplinary Approach to the Study of Land Degradation, In: Dealing with diversity, 2nd Inter. Conf. of the Europ. Soc. F. Envir. History, Proceedings, Charles University in Prague, pp. 154-159.

Goudie, A. S. - Boardman, J. (2010) Soil Erosion, In: Alcántara - Ayala, I., GOUDIE, A. S., (eds): Geomorphological Hazards and Disaster Prevention, Cambridge University Press, NY, pp. 245-255.

Heinrichová, M. (2012) Social Expression and Values of a Historical Landscape (Spoločenský prejav a hodnoty historickej krajiny). STU, Bratislava, $152 \mathrm{pp}$.

Hlavčová, K. - Holko, L. - Szolgay, J. (2001) Runoff Generation and Modelling on Hillslopes and in Small Catchments (Tvorba a modelovanie odtoku na svahoch a z malých povodí. In: Environment, 35,3 .

Hofierka, J. - Koco, Š. (2005) Modeling the Inception of Gully Erosion Around the Town of Bardejov Using a Geographic Information System (Modelovanie vzniku výmolovej erózie v okoli Bardejova pomocou geografických informačných systémov), Folia Geographica 8, Vol. XLIII, Prešov, pp. 233-247.

Janečko, E. - Krébes, G. - Cifra, J. (1955) Degraded Soils and Their Afforestation, (Spustnuté pôdy a ich zalesňovanie), SVPL, Bratislava, $129 \mathrm{pp}$

KLEIN, B. (2002) Slovak Region on the Maps of the 18th Century, 240 Years of Technical Education in Slovakia. Proceedings of Science Conference - Section Cartography-Geodesy-Water Resources Management, STU, Bratislava, pp. 17-20

Kvitkovič, J. (2005) The Use of the 1. Military Mapping for Research in Physical-Geographical Changes in the East-Slovakia Lowland. (Využitie máp 1.vojenského mapovania na štúdium fyzickogeografických zmien Východoslovenskej nižiny), Historical Map, Proceedings of Scientific Conference, Bratislava, ISBN 80-968365-7-9.

Maliariková, M., Nosko R., Látková T., Skalová J., Minarič P. (2016) The Possibilities for Valuation of Water Retention Curves for the Myjava River Basin (Možnosti stanovenia vlhkostných retenčných kriviek pre povodie rieky Myjava). Acta Hydrologica Slovaca, Vol. 17, No. 2, Bratislava, pp. 3-14.

Midriak, R. (2003) Current Analysis and Oultline of Expected Changes in a Landscape from an Ecological Viewpoint. (Analyza súčasných a náčrt očakávaných zmien v krajine z ekologického hl'adiska) In: Olah, B., IV. Ecological Days, Ecological study, Slovak Academy of Science, Banská Štiavnica, pp. 78-87.

Midriak, R. - Zaušková, L. (2011) Degraded Landscapes in Slovakia. (Pustnutie pôdy a pustnutie krajiny Slovenska), Geographica Cassoviensis, Vol. V., No. 1, pp. 79-83.

Midriak, R. (2011), Degraded Landscapes in Slovakia (Spustnuté pôdy a pustnutie krajiny Slovenska), Matej Bel University, Banská Bystrica, ISBN 978-80-557-0110-3, 401 pp.

Papčo, P. (2005) Use of Older Cadastral Maps in Research on Gully Erosion. (Využitie staršich katastrálnych máp pri štúdiu výmol'ovej erózie), Historical maps - Proceedings from scientific conference, Bratislava, ISBN 80-968365-7-9, ISSN 1336-6262, pp. 142-147.

Papčo, P. (2011) Gully Erosion over Time - Maps Versus Correlative Sediments (case study). Geographical letter, 63, 3, pp. 287-298.

Pišút, P. - Procházka, J. - Bandura, P. (2016), Budra Mountains on Historical Maps. (Pohorie Burda na staršich mapách), Nature Conservation, 27, Banská Bystrica, pp. 5-21.

Stankoviansky, M. (1997) Anthropogenic Changes in the "Kopaničiarska" Region in Myjava. (Antropogénne zmeny krajiny Myjavskej kopaničiarskej oblasti). Environment, 31(2), 6 pp.

Stankoviansky, M. (1997) Geomorphic effect of surface runoff in the Myjava Hills, Slovakia, Zeitschrift fur Geomorphologie, Suppl.-Band, pp. 207-217.

Stankoviansky, M. (2004) Changes in the Network of Historical Gullies in the Slovak Climate Conditions. (Historický vývoj výmol'ovej siete v podmienkach Slovenska), The Third Soil Days in SR, Mojmírovce, pp. 279-286.

Stankoviansky, M. (2008) The Environmental Impact and Pedogeomorphological Effect of Mud Floods. (Environmentálny dopad a pedogeomorfologický efekt bahenných povodni), Proceedings, In: Environmental Aspects of an Analysis and Evaluation of the Landscape, Bratislava, pp. 78-85.

Stankoviansky, M., Pišút, P. (2011) Geomorphic Response to the Little Ice Age in Slovakia, Geographia Plonica, 84, Special Issue, Part 1, pp 127-146.

Valent, P. - Rončák, P. - Maliariková, M. - Behan, Š. (2016) Utilization of Historical Maps in the Land Use Change Impact Studies: A Case Study from the Myjava River Basin, Slovak Journal of Civil Engineering, Vol. 24, No. 4, pp. 15-26, ISSN 1210-3896, DOI: $10.1515 /$ sjce-2016-0018.

Zaušková, L. - Midriak, R. (2009) Desertion of Slovakia's Land Hazard or Opportunity in an Economic Crisis, Impacts of the Financial and Economic Crisis on Agriculture: Possible Solutions (Pustnutie krajiny Slovenska - hazard, alebo šanca v hospodárskej kríze?, Dosahy finančnej a hospodárskej krízy na pôdohospodárstvo - možnosti riešenia), Proceedings of the scientific debate of the $34^{\text {th }}$ General Assembly of the Slovak Academy of Agricultural Sciences, Centre for Animal Production Research in Nitra in Lužianky, pp. 78-85.

Žarnovičan, H. (2008) Forest Communities in the Eastern Part of the Myjava Highlands (Lesné spoločenstvá východnej časti Myjavskej Pahorkatiny), Phytopedon, Vol, 7, No. pp. 230-239. 